\title{
Solanine reverses multidrug resistance in human myelogenous leukemia K562/ADM cells by downregulating MRP1 expression
}

\author{
YING-JIE YI ${ }^{1}$, XIU-HONG JIA ${ }^{1}$, CONG ZHU ${ }^{1}$, JIAN-YONG WANG ${ }^{1}$, \\ JIE-RU CHEN ${ }^{1}$, HONG WANG ${ }^{1}$ and YOU-JIE LI ${ }^{2}$ \\ ${ }^{1}$ Department of Pediatrics, The Affiliated Hospital of Binzhou Medical University, Binzhou, Shandong 256603; \\ ${ }^{2}$ Department of Biochemistry and Molecular Biology, Key Laboratory of Tumor Molecular Biology, \\ Binzhou Medical University, Yantai, Shandong 264003, P.R. China
}

Received August 7, 2015; Accepted November 3, 2016

DOI: $10.3892 / \mathrm{ol} .2018 .8563$

\begin{abstract}
Multidrug resistance (MDR) in leukemia cells is a major obstacle to chemotherapeutic treatment. High expression and constitutive activation of multidrug resistance protein 1 (MRP1) has been associated with the development of resistance to anticancer drugs in a number of tumor types. The activity of c-Jun N-terminal kinase 1 (JNK1) is associated with the occurrence of MDR and MRP1 expression. The present study aimed to investigate the ability of solanine to resensitize the Adriamycin ${ }^{\circledR}$ (ADR)-resistant human myelogenous leukemia cell line K562/ADM to ADR. Results of the Cell Counting Kit- 8 assay demonstrated that solanine inhibited K562/ADM cell proliferation. K562/ADM cell sensitivity to ADR was increased following treatment with solanine, indicated by increased intracellular accumulation of ADR. Western blotting demonstrated that treatment with solanine led to reduced MRP1 protein expression, suggesting that solanine-induced ADR accumulation is due to the downregulation of MRP1 expression. Solanine-mediated MRP1 downregulation was observed to be dependent on the JNK signaling pathway. In conclusion, the results of the present study suggest that solanine reverses MDR in K562/ADM cells and may represent a novel therapeutic agent for the treatment of human myelogenous leukemia.
\end{abstract}

\section{Introduction}

Chronic myelogenous leukemia (CML) is one of the most frequent types of cancer in humans and its treatment is limited by the development of multidrug resistance (MDR) (1). MDR is a phenomenon in which cancer cells develop resistance to

Correspondence to: Professor Xiu-Hong Jia, Department of Pediatrics, The Affiliated Hospital of Binzhou Medical University, 661 Second Yellow River Road, Binzhou, Shandong 256603, P.R. China

E-mail: jiaxiuhong001@163.com

Key words: multidrug resistance, solanine, reverse, multidrug resistance protein 1 , phosphorylated-c-Jun N-terminal kinase 1 a variety of unrelated drugs following exposure to a single chemotherapeutic (2). A number of underlying mechanisms lead to the development of MDR; however, the increased efflux of cytotoxic drugs by ATP binding cassette (ABC) transporters is the most well studied mechanism (3). Multidrug resistance protein 1 (MRP1) is a member of the $\mathrm{ABC}$ family of transporters, which are primarily expressed in the plasma membrane and remove cytotoxic agents from the cell through active transport (4). Increased MRP1 expression leads to a reduction in the concentration of chemotherapeutics inside tumor cells, resulting in the decreased efficacy of these agents (5-10). MRP1 has been associated with resistance to various chemotherapeutic agents, including Adriamycin ${ }^{\circledR}$ (ADR; doxorubicin), methotrexate, etoposide and vincristine (11).

The c-Jun N-terminal kinases (JNK) belong to the mitogen-activated protein kinase (MAPK) family (12). There are three JNK isoforms in mammals, JNK1, JNK2 and JNK3, which are encoded by the MAPK8, MAPK9 and MAPK10 genes, respectively (13). JNK1 and JNK2 are ubiquitously expressed, whereas JNK3 is primarily expressed in the heart, brain and testes (14). JNK activity can be induced by a number of stimuli, including inflammatory cytokines, environmental stressors and therapeutic agents (15). The JNK signaling pathway has been reported to be involved in cellular proliferation, apoptosis and differentiation, and tumor cell migration $(16,17)$. Increasing evidence has indicated that JNK activity serves an important role in the development of chemoresistance and is associated with MRP1 expression (12-16).

Nightshade (Solanum nigrum) is used in traditional Chinese herbal medicine, and is used to treat a number of diseases including sores, carbuncles, swellings and other injuries (18). Solanine, a nightshade extract, is a glycoalkaloid belonging to the Solanaceae family, which is reported to have anti-inflammatory activity $(19,20)$. Recently, studies have demonstrated antitumorigenic effects of solanine in various types of cancer cell, for example, solanine suppresses proliferation and metastasis, and induces apoptosis in pancreatic cancer cells $(19,21)$. Solanine was demonstrated to induce apoptosis in HepG2 cells by facilitating the opening of mitochondrial permeability transition pores (22) and downregulating expression of 
apoptosis regulator Bcl-2 (Bcl-2) (23). Previous studies have demonstrated that solanine inhibits the invasion of human melanoma and prostate cancer cells at non-toxic doses $(18,24)$. Furthermore, Kang et al (25) reported that solanine is able to inhibit JNK activity. However, the underlying molecular mechanisms behind the effect of solanine on MDR cancer cells remain to be elucidated. The present study aimed to investigate the ability of solanine to resensitize the ADR-resistant human myelogenous leukemia cell line K562/ADM to ADR, in addition to the mechanisms underlying its effects.

\section{Materials and methods}

Reagents. ADR (Melone Pharmaceutical Co., Ltd., Dalian, China) was made up to a final concentration of $2 \mathrm{~g} / \mathrm{l} \mathrm{using}$ double-distilled $\mathrm{H}_{2} \mathrm{O}$. Solanine (Sigma-Aldrich; Merck Millipore, Darmstadt, Germany) was made up to a final concentration of $100 \mu \mathrm{g} / \mathrm{ml}$ using dimethyl sulfoxide (DMSO) and diluted as required using RPMI-1640 cell culture medium (Hyclone; GE Healthcare Life Sciences, Logan, UT, USA). PBS buffer (Shanghai MacLean Biochemical Technology Co., Ltd., Shanghai, China). Rabbit polyclonal anti-MRP1, anti-JNK and anti-phosphorylated (p)-JNK (Thr ${ }^{183} / \mathrm{Thr}^{185}$ ) antibodies were obtained from Beijing Biosynthesis Biotechnology Co., Ltd. (Beijing, China). The anti-JNK antibody detects all JNK isoforms. The rabbit polyclonal anti-GAPDH antibody was obtained from Goodhere Biotechnology Co., Ltd. (Hangzhou, China).

Cell lines and culture. The human CML K562 cell line was obtained from the Key Laboratory of Tumor Molecular Biology of Binzhou Medical University (Binzhou, China) with the original source from the Department of Pharmacology at the Institute of Hematology of Chinese Academy of Medical Sciences (Tianjin, China). The MDR-resistant subline, K562/ADM, was obtained from the Department of Pharmacology at the Institute of Hematology of Chinese Academy of Medical Sciences. Cells were cultured in RPMI-1640 medium supplemented with $10 \%$ fetal bovine serum (Hyclone; GE Healthcare Life Sciences) at $37^{\circ} \mathrm{C}$ in a humidified atmosphere containing 5\% $\mathrm{CO}_{2}$. K562/ADM cells were maintained in medium containing $4 \mathrm{mg} / \mathrm{l} \mathrm{ADR}$, but cultured in drug-free medium for one week prior to experimentation.

Determination of MDR accumulation in K562/ADM cells The Cell Counting Kit-8 (CCK-8; Dojindo Molecular Technologies, Inc., Shanghai, China) assay was used to determine the viability of CML cells. The CML cells $\left(1 \times 10^{5}\right.$ cells/well) were incubated (humidified atmosphere, $37^{\circ} \mathrm{C}, 5 \% \mathrm{CO}_{2}$ for $24 \mathrm{~h}$ ) with $\mathrm{ADR}$ at the following concentrations: $0.2-1.6 \mathrm{mg} / 1$ for $\mathrm{K} 562$ cells; and $16-128 \mathrm{mg} / \mathrm{l}$ for K562/ADM cells. RPMI-1640 medium was used to dissolve ADR. A total of $10 \mu \mathrm{l}$ CCK- 8 solution was added to each well $24 \mathrm{~h}$ following incubation. The plates were incubated for $1-4 \mathrm{~h}$ at $37^{\circ} \mathrm{C}$ in a humidified atmosphere containing $5 \%$ $\mathrm{CO}_{2}$. Absorbance was subsequently measured at $570 \mathrm{~nm}$ using an F-7000 Fluorescence Spectrophotometer (Hitachi, Ltd., Tokyo, Japan). A blank well containing RPMI-1640 medium and ADR alone was used as a control. The half-maximal inhibitory concentration $\left(\mathrm{IC}_{50}\right)$ of cell growth was calculated as described previously (26).

Solanine cytotoxicity assay. Solanine cytotoxicity was evaluated using the CCK-8 assay as described above. K562/ADM cells $\left(1 \times 10^{5}\right)$ were seeded into a 96 -well plate and incubated with between 5 and $10 \mu \mathrm{g} / \mathrm{ml}$ solanine at $37^{\circ} \mathrm{C}$ for $24 \mathrm{~h}$. Cells in the control group were incubated with DMSO alone. The number of viable cells was determined using the CCK-8 assay, as described above.

Evaluating the MDR reversal efficacy of solanine. K562/ADM cells $\left(1 \times 10^{5}\right)$ were seeded into 96 -well plates and treated with $0-128 \mu \mathrm{g} / \mathrm{ml}$ ADR alone or $0-128 \mu \mathrm{g} / \mathrm{ml}$ ADR combined with $5-10 \mu \mathrm{g} / \mathrm{ml}$ solanine for $24 \mathrm{~h}$ at $37^{\circ} \mathrm{C}$. Cell viability was subsequently assessed using the CCK-8 assay, which was performed five times. $\mathrm{IC}_{50}$ values were calculated and untreated cells were used as the negative control. Reversal fold (RF) values were used to quantify sensitivity reversal and were obtained using the following formula: $\mathrm{RF}=\mathrm{IC}_{50}$ of $\mathrm{ADR}$ treatment alone/ $\mathrm{IC}_{50}$ of combined ADR and solanine treatment.

Evaluating intracellular ADR accumulation. K562/ADM cells were incubated for $1 \mathrm{~h}$ at $37^{\circ} \mathrm{C}$ with $3 \mathrm{mg} / 1 \mathrm{ADR}$ alone or in combination with $5-10 \mu \mathrm{g} / \mathrm{ml}$ solanine. Cells were subsequently harvested using centrifugation (room temperature) at $150 \mathrm{x} \mathrm{g}$ for $5 \mathrm{~min}$ and washed twice with ice-cold PBS to remove the unbound ADR. The cell-associated mean fluorescence intensity of ADR-treated cells was detected using an FC500 Flow Cytometry Analyzer (Beckman Coulter, Inc., Brea, CA, USA), and the respective excitation and emission wavelengths were 485 and $580 \mathrm{~nm}$.

Western blot analysis. K562/ADM cells were incubated with $5-10 \mu \mathrm{g} / \mathrm{ml}$ solanine at $37^{\circ} \mathrm{C}$ in a humidified atmosphere containing $5 \% \mathrm{CO}_{2}$ for $24 \mathrm{~h}$ prior to harvesting. Cells were lyzed in $100 \mu \mathrm{l}$ lysis buffer (Beyotime Institute of Biotechnology, Haimen, China) and the total protein concentration was determined using a BCA Protein Assay kit (Beyotime Institute of Biotechnology). A total of $50 \mu \mathrm{g}$ total protein was separated using SDS-PAGE on 6-8\% gels depending on the molecular mass of the protein (initial voltage, $80 \mathrm{~V}$; initial duration, $30 \mathrm{~min}$; final voltage, $100 \mathrm{~V}$; final duration, $1.5 \mathrm{~h}$ ). Resolved proteins were transferred to a polyvinylidene difluoride membrane (EMD Millipore, Billerica, MA, USA) and blocked at room temperature with $5 \%$ skimmed milk for $2 \mathrm{~h}$. Membranes were subsequently incubated overnight at $4{ }^{\circ} \mathrm{C}$ with rabbit polyclonal anti-MRP1 (1:500), anti-JNK (1:200), anti-p-JNK (1:500) and anti-GADPH (1:1,000) antibodies. Membranes were incubated with horseradish peroxidase-labeled goat anti-rabbit immunoglobulin G (1:5,000; Beijing Biosynthesis Biotechnology Co., Ltd., Beijing China) for $2 \mathrm{~h}$ at room temperature. Images were captured using a FluorChem FC2 Imaging system (Alpha Innotech, San Leandro, CA, USA). The intensity of each band was normalized to GADPH and quantified using ImageJ software 2x v.2.1.4.7 (National Institutes of Health, Bethesda, MD, USA).

Statistical analysis. Statistical analysis was performed using SPSS software (version 13.0; SPSS, Inc., Chicago, IL, 
Table I. Determination of $\mathrm{ADR} \mathrm{IC}_{50}$ values in the $\mathrm{K} 562$ and $\mathrm{K} 562 / \mathrm{ADM}$ cell lines.

\begin{tabular}{lccc}
\hline & \multicolumn{2}{c}{$\mathrm{IC}_{50}(\mu \mathrm{g} / \mathrm{ml})$} & \\
\cline { 2 - 3 } Treatment & $\mathrm{K} 562 / \mathrm{ADM}$ & $\mathrm{K} 562$ & Fold increase in resistance \\
\hline ADR & $52.4579 \pm 1.0874^{\mathrm{a}}$ & $1.3966 \pm 0.01526$ & 37.56115
\end{tabular}

Values are presented as the mean \pm standard deviation $(n=3)$. ${ }^{a} \mathrm{P}<0.05$ vs. $\mathrm{K} 562$ cells. ADR, Adriamycin; $\mathrm{IC}_{50}$, half-maximal inhibitory concentration.

USA). Values are presented as the mean \pm standard deviation. Statistical comparisons were evaluated using one-way analysis of variance followed by Student-Newman-Keuls test. $\mathrm{P}<0.05$ was considered to indicate a statistically significant difference.

\section{Results}

Comparing the ADR resistance of $K 562$ and K562/ADM cells. K562/ADM cells exhibited significant resistance to ADR compared with the non-ADR resistant K562 cell line $(\mathrm{P}<0.05$; Table I). As shown in Table I, a 37.56115 fold increase in ADR resistance was observed in the K562/ADM cells compared with the K562 cells $(\mathrm{P}<0.05)$.

Effect of solanine on K562/ADM cell proliferation. Treatment with solanine inhibited K562/ADM cell proliferation in a dose-dependent manner (Fig. 1). Treatment with 5 or $10 \mu \mathrm{g} / \mathrm{ml}$ solanine had no marked inhibitory effect on cell proliferation ( $<5$ and $<10 \%$ vs. the control group, respectively). Therefore, these concentrations were selected for subsequent experiments, as they had little effect on K562/ADM cell proliferation.

Effect of combined treatment with ADR and solanine on K562/ADM cell sensitivity to ADR. To determine whether combined treatment with ADR (range, $0-128 \mu \mathrm{g} / \mathrm{ml}$ ) and 5 or $10 \mu \mathrm{g} / \mathrm{ml}$ solanine had an effect on drug resistance in vitro, cytotoxicity was assessed using the CCK-8 assay (Fig. 2; Table II). The results demonstrated a significantly decreased rate of proliferation in K562/ADM cells $24 \mathrm{~h}$ following combined treatment with ADR and solanine, compared with treatment with ADR alone ( $\mathrm{P}<0.05$; Fig. 2; Table II). This suggests that combined treatment with solanine increases ADR cytotoxicity in K562/ADM cells. Combined treatment with 5 and $10 \mu \mathrm{g} / \mathrm{ml}$ solanine led to a 1.68 and 2.64 fold increase in K562/ADM sensitivity to ADR, respectively $(\mathrm{P}<0.05$ vs. ADR treatment alone; Table II).

Solanine increases the intracellular accumulation of $A D R$. In a previous study, intracellular accumulation of ADR was reported to be significantly decreased in K562/ADM cells compared with K562 cells (7). In the present study, it was determined that solanine significantly increased the intracellular accumulation of ADR in K562/ADM cells ( $\mathrm{P}<0.05$ vs. the control group; Fig. 3). These results indicate that solanine increases the sensitivity of K562/ADM cells to ADR by increasing intracellular ADR accumulation.

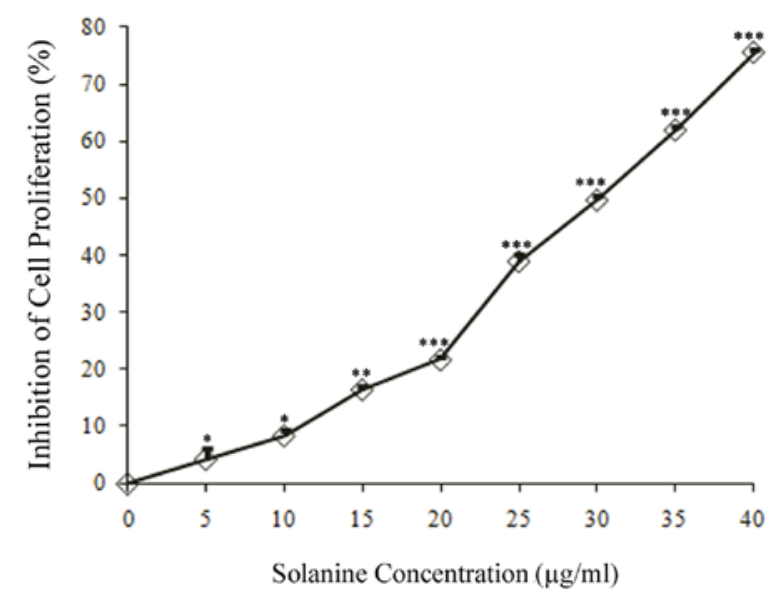

Figure 1. Effect of treatment with solanine on K562/ADM cell proliferation. K562/ADM cells were treated with solanine for $24 \mathrm{~h}$. Proliferation of K562/ADM cells was determined using the Cell Counting Kit-8 assay and the inhibition rate $(\%)$ of proliferation was calculated. Values are presented as the mean \pm standard deviation of triplicate experiments. ${ }^{*} \mathrm{P}<0.05,{ }^{* *} \mathrm{P}<0.01$, ${ }^{* * * *} \mathrm{P}<0.001$ vs. untreated cells.

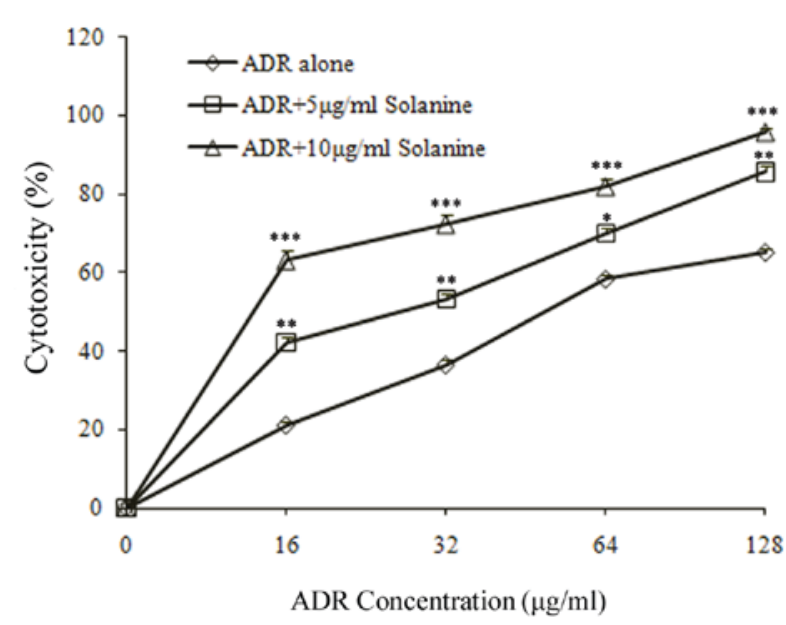

Figure 2. Effect of treatment with solanine on ADR cytotoxicity. Growth curves produced using data from Cell Counting Kit-8 assays in K562/ADM cells treated with ADR alone or ADR in combination with 5 or $10 \mu \mathrm{g} / \mathrm{ml}$ solanine. Values are presented as the mean \pm standard deviation of triplicate experiments. ${ }^{*} \mathrm{P}<0.05,{ }^{* *} \mathrm{P}<0.01,{ }^{* * *} \mathrm{P}<0.001$ vs. ADR alone treatment group. ADR, Adriamycin ${ }^{\circledR}$.

Treatment with solanine decreases MRP1 protein expression in K562/ADM cells. MRP1 is an ABC transporter, which is overexpressed in numerous drug-resistant cell lines, including K562/ADM cells, compared with the corresponding 
Table II. Effect of treatment with solanine on the ADR $\mathrm{IC}_{50}$ values in K562/ADM cells.

\begin{tabular}{lcc}
\hline Treatment & $\mathrm{IC}_{50}(\mu \mathrm{g} / \mathrm{ml})$ & $\begin{array}{c}\text { Fold reversal } \\
\text { vs. ADR alone }\end{array}$ \\
\hline ADR alone & $54.7985 \pm 1.71941$ & N/A \\
ADR $+5 \mu \mathrm{g} / \mathrm{ml}$ solanine & $32.6094 \pm 0.66628^{\mathrm{a}}$ & 1.68 \\
ADR $+10 \mu \mathrm{g} / \mathrm{ml}$ solanine & $14.7863 \pm 0.61516^{\mathrm{a}}$ & 3.71 \\
\hline
\end{tabular}

Values are presented as the mean \pm standard deviation $(\mathrm{n}=3) .{ }^{\mathrm{a}} \mathrm{P}<0.05$ vs. treatment with $\mathrm{ADR}$ alone. $\mathrm{ADR}$, Adriamycin; $\mathrm{IC}_{50}$, half-maximal inhibitory concentration.

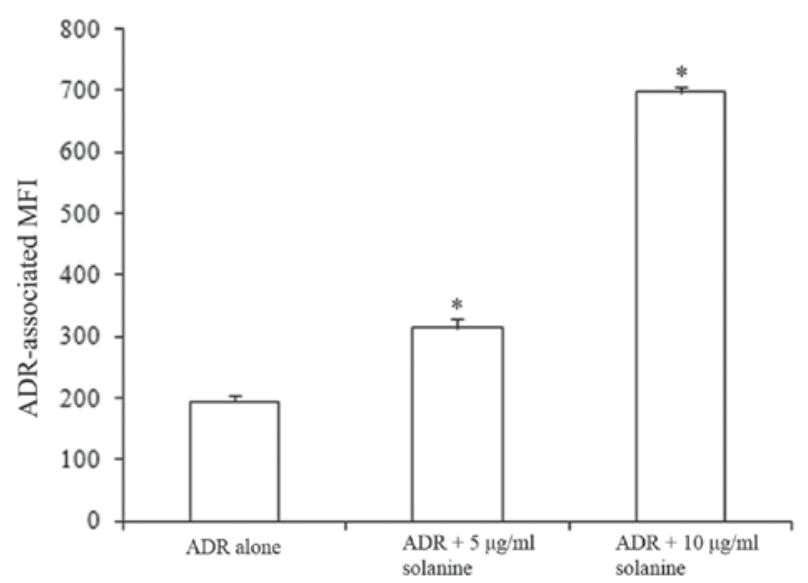

Figure 3. Solanine increases intracellular accumulation of ADR. Cells were treated with $3 \mathrm{mg} / \mathrm{l}$ ADR alone or in combination with 5 or $10 \mu \mathrm{g} / \mathrm{ml}$ solanine for $1 \mathrm{~h}$. Following removal of the unbound ADR, the cell-associated ADR MFI was evaluated using flow cytometry, with excitation and emission wavelengths of 485 and $585 \mathrm{~nm}$, respectively. Values are presented as the mean \pm standard deviation of triplicate experiments. ${ }^{*} \mathrm{P}<0.05$ vs. ADR alone treatment group. ADR, Adriamycin; MFI, mean fluorescence intensity.

non-resistant cell lines (11). K562/ADM cells were identified to express MRP1 protein at high levels (11). Western blot analysis demonstrated that MRP1 protein expression was significantly decreased in $\mathrm{K} 562 / \mathrm{ADM}$ cells following treatment with 5 or $10 \mu \mathrm{g} / \mathrm{ml}$ solanine compared with the untreated cells $(\mathrm{P}<0.05$; Fig. 4). These results indicate that solanine increases MRP1 protein expression, which likely increases intracellular ADR accumulation.

Treatment with solanine decreases JNK phosphorylation. JNK serves an essential role in the development of MDR, therefore the phosphorylation pattern of JNK in MDR K562/ADM cells was analyzed using western blotting. As shown in Fig. 5, total JNK expression did not change significantly $24 \mathrm{~h}$ following treatment with solanine compared with the control group ( $\mathrm{P}>0.05$; Fig. 5A and B); however, the expression of $\mathrm{p}-\mathrm{JNK}$ was significantly decreased in a dose-dependent manner compared with the untreated cells $(\mathrm{P}<0.05$; Fig. 5A and $\mathrm{C})$. The effect of treatment with solanine on JNK phosphorylation was consistent with its effect on MRP1 expression. These results suggest that the JNK signaling pathway participates in the modulation of MRP1 protein expression.

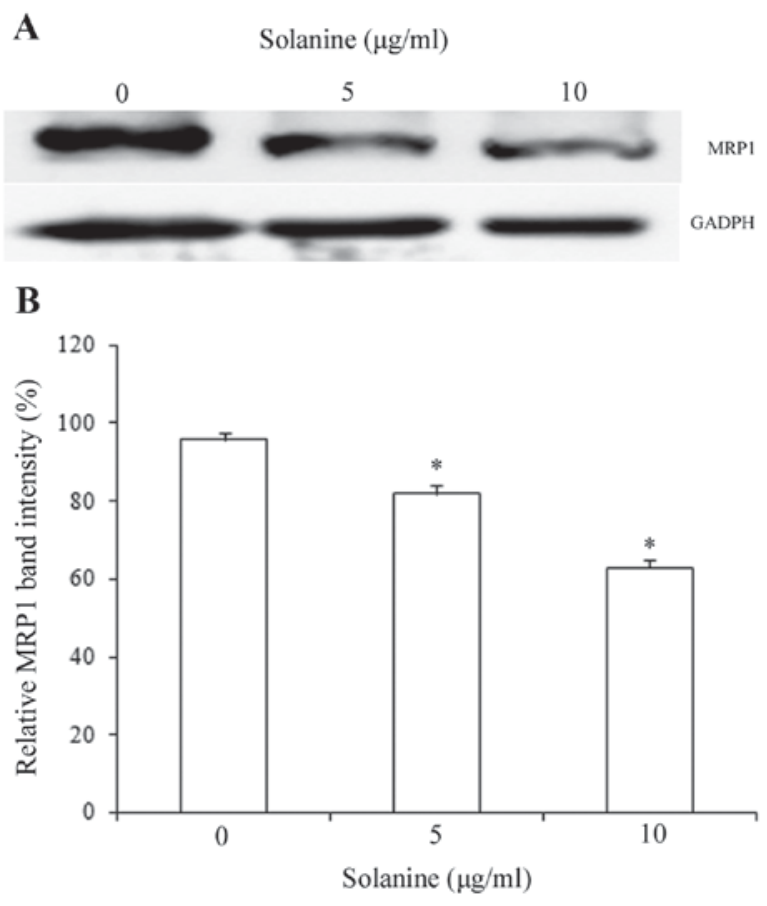

Figure 4. Treatment with solanine decreases MRP1 protein expression in K562/ADM cells. (A) Western blot of MRP1 protein expression. (B) Quantification of western blot, normalized to GAPDH. Treatment with solanine significantly inhibited MRP1 expression. Values are expressed as the mean \pm standard deviation of triplicate experiments. ${ }^{*} \mathrm{P}<0.05$ vs. untreated cells. MRP1, multidrug resistance protein 1.

\section{Discussion}

CML is a stem-cell disorder characterized by chronic and blast crisis phases (27). Chemotherapy serves an essential role in CML treatment; however, it is frequently accompanied by the development of MDR, which results in treatment failure. MDR is the ability of tumors to exhibit simultaneous resistance to a number of structurally and functionally unrelated chemotherapeutic agents (28). There are multiple underlying molecular mechanisms of MDR, including increased expression of $\mathrm{ABC}$ transporter proteins, and abnormalities in a number of enzymatic and apoptotic signaling pathways (28). ADR is an effective chemotherapeutic that has been used extensively to treat CML, but is limited by the development of MDR (1). MRP1 overexpression is one of the well-known causes of MDR (11). Significant efforts have been made to identify novel MDR-inhibiting agents.

Glycoalkaloids are secondary plant metabolites that contain nitrogen, are found in solanaceous plants and possess anticarcinogenic activity (29). Nightshade is a plant used in traditional Chinese herbal medicine (24), which contains the glycoalkaloid solanine (21). Increasing evidence has demonstrated that solanine possesses antitumor activity, for example, solanine has been demonstrated to inhibit the growth of U937 cells (30). In addition, previous studies revealed that solanine has antitumor activity in other types of cancer (18-19,21). A previous study suggested that Solanine suppressed proliferation of mouse breast cancer cells by inducing expression of the apoptosis regulator $\mathrm{Bcl} 2$ associated $\mathrm{X}$ (Bax) and decreasing expression of Bcl-2 (30). Solanine was demonstrated to inhibit 
A Solanine $(\mu \mathrm{g} / \mathrm{ml})$

0

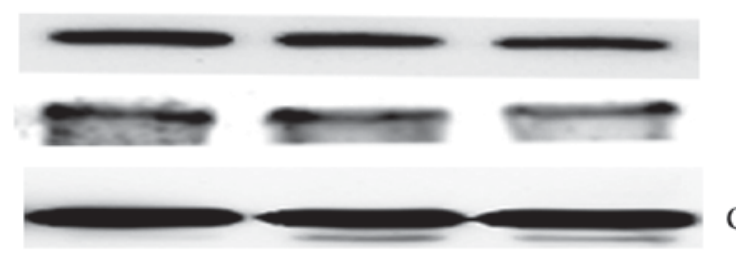

GADPH

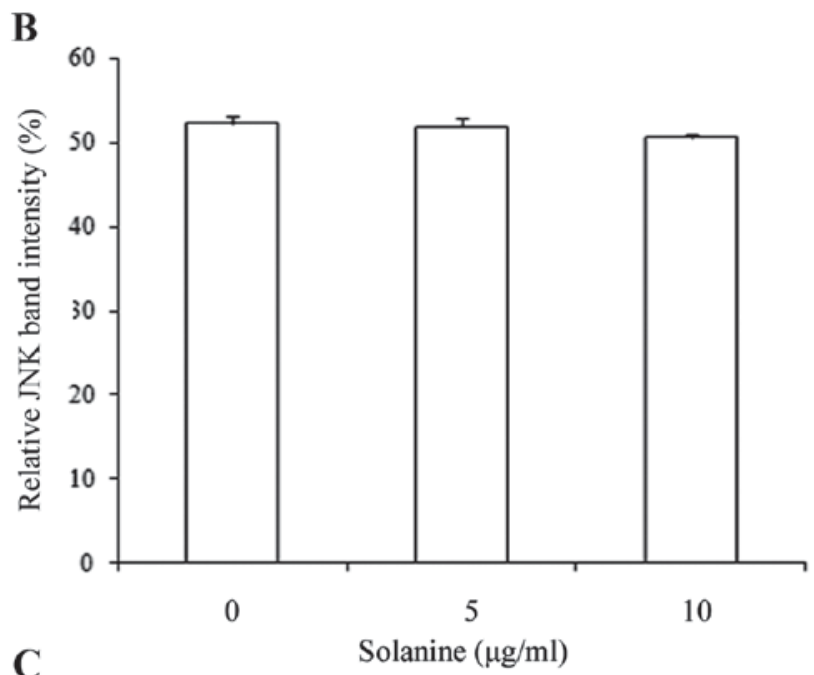

C

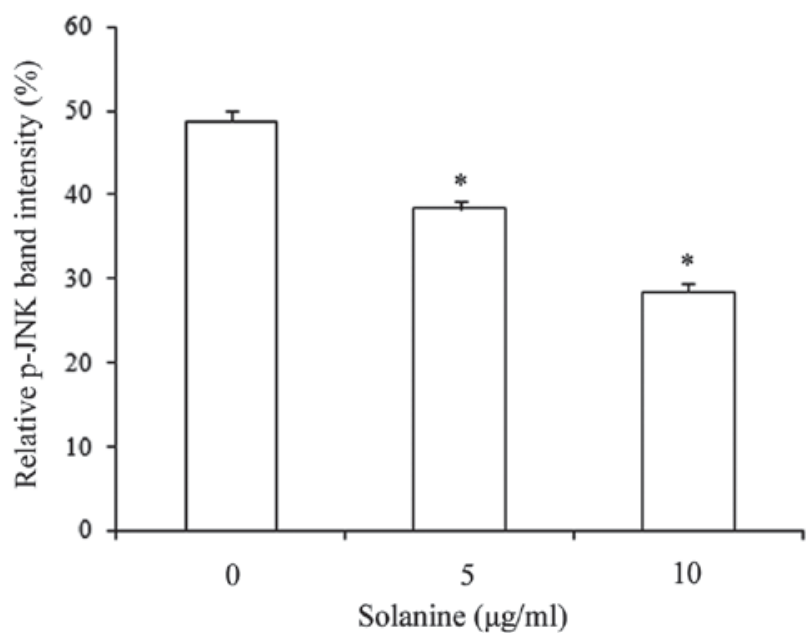

Figure 5. Effect of treatment with solanine on the total expression of JNK and JNK phosphorylation status. (A) K562/ADM cells were treated with 0,5 or $10 \mu \mathrm{g} / \mathrm{ml}$ solanine for $24 \mathrm{~h}$ and analyzed using western blotting for expression of JNK and p-JNK. Quantification of western blot for (B) JNK and (C) p-JNK protein expression, normalized to GAPDH. p-JNK expression decreased following treatment with solanine. Values are presented as the mean \pm standard deviation of triplicate experiments. ${ }^{*} \mathrm{P}<0.05$ vs. untreated cells. JNK, c-Jun N-terminal kinase; p-, phosphorylated.

the activity of matrix metalloproteinase (MMP)-2 and -9 by suppressing the phosphatidylinositol 4,5-bisphosphate 3-kinase/protein kinase B and JNK signaling pathways at non-toxic doses, which resulted in the inhibition of melanoma cell migration and invasion (18). In addition, it was reported that treatment with solanine suppressed MMP-2 and 9 expression in pancreatic cancer cells at toxic doses, which resulted in the suppression of pancreatic cancer cell migration and invasion $(19,21)$. Furthermore, treatment with solanine decreased the $\mathrm{Bcl}-2 / \mathrm{Bax}$ ratio and induced activation of the capase-3 zymogen to facilitate pancreatic cancer cell apoptosis (19). However, the effect of treatment with solanine on the reversal of MDR in K562/ADM cells was unclear. The present study aimed to investigate the effects and underlying mechanisms of solanine action in K562/ADM cells.

In the present study, the efficacy of solanine as a reverser of ADR resistance in K562/ADM cells was examined. The results suggested that treatment with 5 or $10 \mu \mathrm{g} / \mathrm{ml}$ solanine alone exhibited no significant antiproliferative effect on K562/ADM cells compared with the control group. The effect of treatment with solanine on cellular functions in K562/ADM cells was subsequently investigated. The CCK-8 assay demonstrated that treatment with 5 and $10 \mu \mathrm{g} / \mathrm{ml}$ solanine enhanced the cytotoxicity of ADR to K562/ADM cells, suggesting that solanine reverses MDR in K562/ADM cells. The results of the flow cytometric assay demonstrated that treatment with solanine increased the intracellular accumulation of ADR, which suggests that this is the mechanism through which solanine reverses MDR. To further examine the mechanism by which solanine elevates K562/ADM intracellular ADR accumulation, MRP1 protein expression was evaluated.

MRP1, an ATP-dependent molecular pump, is a member of the $\mathrm{ABC}$ transporter protein family and is able to decrease intracellular drug accumulation, thus decreasing the cellular toxicity of various chemotherapeutic agents, including ADR, daunorubicin, epirubicin, mitoxantrone, bisantrene, vincristine, vinblastine, etoposide and paclitaxel $(11,31)$. In the present study, western blot analysis demonstrated that treatment with solanine significantly decreased MRP1 protein expression compared with treatment with ADR alone in K562/ADM cells. Decreased expression of MRP1 protein was associated with increased intracellular accumulation of ADR in K562/ADM cells.

It has been reported that the JNK signaling pathway is involved in the development of MDR in a number of tumor cell types. Decreased JNK activity has been observed in drug-resistant hepatocellular carcinoma cells, while increased JNK activity was demonstrated to attenuate chemoresistance in R-HepG2 cells by suppressing P-glycoprotein (P-gp) expression $(32,33)$. Increased JNK signaling pathway activation was identified to downregulate P-gp expression and reverse P-gp-mediated MDR in gastric and pancreatic cancer cells (17). However, decreased JNK phosphorylation has been demonstrated to inhibit P-gp expression during hypoxia $(14,34)$. Increasing evidence has demonstrated that JNK activity is associated with MRP1 activity and expression. Suppression of the JNK signaling pathway led to a decrease in MRP1 activity and expression in glial cells (35). However, MRP1 expression was negatively associated with JNK activity in another study (36). Cripe et al (37) reported that JNK activity and MRP1 expression were upregulated in HL60/ADR cells compared with HL60 cells and furthermore, that inhibition of JNK activity decreased MRP1-efflux and MRP1 protein expression. These results indicate that JNK activity serves an important role in the development of MDR and MRP1 expression. Cripe et al (37) also reported that JNK activity was upregulated in K562 cells, and in tumor cells exposed to ADR in a time- and concentration-dependent manner. As expected, in the present study treatment with solanine led to inhibited JNK activity while having no 
significant impact on total JNK expression. The results of the present study indicate that decreased JNK activity is associated with the inhibition of MRP1 expression in K562/ADM cells, suggesting that solanine is able to reverse MDR by modulating the expression of MRP1, through regulation of the JNK signaling pathway.

In conclusion, treatment with solanine enhanced the sensitivity of K562/ADM cells to ADR as a result of increased intracellular ADR accumulation, which was associated with the downregulation of MRP1 expression. Downregulated MRP1 expression was likely a result of decreased JNK phosphorylation, a marker of JNK activity. The results of the present study suggest that solanine is a novel therapeutic agent for the treatment of cancer, which reverses MDR in human myelogenous leukemia K562/ADM cells.

\section{Acknowledgements}

Not applicable.

\section{Funding}

The present study was supported by the Shandong Science and Technology Committee (grant no. 2010GSF10264), the Committee of Shandong Educational Foundation (grant nos. J10LC60 and J11LC01), the Natural Science Foundation of Shandong Province (grant no. ZR2014HL032) and the Medical and Health Technology Development Program of Shandong Province (grant no. 2014WS0183).

\section{Availability of data and materials}

The datasets used and/or analyzed during the current study are available from the corresponding author on reasonable request.

\section{Authors' contributions}

YJY was responsible for the main experiments and writing the manuscript. XHJ analyzed experimental data and modified the manuscript. CZ, JYW, JRC, HW conducted some parts of the experiments. YJL designed and guided the experiments. All authors read and approved the final manuscript.

\section{Ethics approval and consent to participate}

Not applicable.

\section{Consent for publication}

Not applicable.

\section{Competing interests}

The authors declare that they have no competing interests.

\section{References}

1. Ren J, Xu Y, Huang Q, Yang J, Yang M, Hu K and Wei K: Chabamide induces cell cycle arrest and apoptosis by the Akt/MAPK pathway and inhibition of P-glycoprotein in K562/ADR cells. Anticancer Drugs 26: 498-507, 2015.
2. Li H, Guo K, Wu C, Shu L, Guo S, Hou J, Zhao N, Wei L, Man X and Zhang L: Controlled and targeted drug delivery by a UV-responsive liposome for overcoming chemo-resistance in non-hodgkin lymphoma. Chem Biol. Drug Des 86: 783-794, 2015.

3. Nabekura T, Hiroi T, Kawasaki T and Uwai Y: Effects of natural nuclear factor-kappa B inhibitors on anticancer drug efflux transporter human P-glycoprotein. Biomed Pharmacother 70: $140-145,2015$

4. Wen X, Zhang HD, Zhao L, Yao YF, Zhao JH and Tang JH: Ginsenoside Rh2 differentially mediates microRNA expression to prevent chemoresistance of breast cancer. Asian Pac J Cancer 16: 1105-1109, 2015.

5. Bao W, Zhu F, Duan Y, Yang Y and Cai H: HtrA1 resensitizes multidrug-resistant hepatocellular carcinoma cells by targeting XIAP. Biomed Pharmacother 70: 97-102, 2015.

6. Wang Z, Yang L, Xia Y, Guo C and Kong L: Icariin enhances cytotoxicity of doxorubicin in human multidrug-resistant osteosarcoma cells by inhibition of $\mathrm{ABCB} 1$ and down-regulation of the PI3K/Akt pathway. Biol Pharm Bull 38: 277-284, 2015.

7. Song YN, Guo XL, Zheng BB, Liu XY, Dong X, Yu LG and Cheng YN: Ligustrazine derivate DLJ14 reduces multidrug resistance of K562/A02 cells by modulating GSTp activity. Toxicol In Vitro 25: 937-943, 2011

8. Ma J, Wang T, Guo R, Yang X, Yin J, Yu J, Xiang Q, Pan X, Tang $\mathrm{H}$ and Lei $\mathrm{X}$ : Involvement of miR-133a and miR-326 in ADM resistance of HepG2 through modulating expression of ABCC1. J Drug Target 25: 519-524, 2015.

9. Yang X, Iyer AK, Singh A, Choy E, Hornicek FJ, Amiji MM and Duan Z: MDR1 siRNA loaded hyaluronic acid-based CD44 targeted nanoparticle systems circumvent paclitaxel resistance in ovarian cancer. Sci Rep 5: 8509, 2015.

10. Fantappiè O, Sassoli C, Tani A, Nosi D, Marchetti S, Formigli L and Mazzanti R: Mitochondria of a human multidrug-resistant hepatocellularcarcinoma cell line constitutively express inducible nitric oxide synthase in the inner membrane. J Cell Mol Med 19: 1410-1417, 2015.

11. Xu X, Zhang Y, Li W, Miao H, Zhang H, Zhou Y, Li Z, You Q, Zhao $L$ and Guo Q: Wogonin reverses multi-drug resistance of human myelogenous leukemia K562/A02 cells via downregulation of MRP1 expression by inhibiting Nrf2/ARE signaling pathway. Biochem Pharmacol 92: 220-234, 2014.

12. Han L, Wang Y, Guo X, Zhou Y, Zhang J, Wang N, Jiang J, Ma F and Wang Q: Downregulation of MDR1 Gene by cepharanthine hydrochloride is related to the activation of c-Jun/JNK in K562/ADR cells. Biomed Res Int 2014: 164391, 2014.

13. Seki E, Brenner DA and Karin M: A liver full of JNK: Signaling in regulation of cell function and disease pathogenesis, and clinical approaches. Gastroenterology 143: 307-320, 2012.

14. Zhang W, Chen BA, Jin JF, He YJ and Niu YQ: Involvement of c-Jun N-terminal kinase in reversal of multidrug resistance of human leukemia cells in hypoxia by 5-bromotetrandrine. Leuk Lymphoma 54: 2506-2516, 2013.

15. Zhu MM, Tong JL, Xu Q, Nie F, Xu XT, Xiao SD and Ran ZH: Increased JNK1 Signaling pathway is responsible for ABCG2-mediated multidrug resistance in human colon cancer. PLoS One 7: e41763, 2012.

16. Zhan X, Feng X, Kong Y, Chen Y and Tan W: JNK signaling maintains the mesenchymal properties of multi-drug resistant human epidermoid carcinoma KB cells through snail and twist1. BMC Cancer 13: 180, 2013.

17. Zhou J, Liu M, Aneja R, Chandra R, Lage H and Joshi HC: Reversal of P-glycoprotein-mediated multidrug resistance in cancer cells by the c-Jun NH2-terminal kinase. Cancer Res 66: 445-452, 2006.

18. Lu MK, Shih YW, Chang Chien TT, Fang LH, Huang HC and Chen PS: $\alpha$-Solanine inhibits human melanoma cell migration and invasion by reducing matrix metalloproteinase-2/9 activities. Biol Pharm Bull 33: 1685-1691, 2010.

19. Sun H, Lv C, Yang L, Wang Y, Zhang Q, Yu S, Kong H, Wang M, Xie J, Zhang C and Zhou M: Solanine induces mitochondria-mediated apoptosis in human pancreatic cancer cells. Biomed Res Int 2014: 805926, 2014.

20. Kenny OM, McCarthy CM, Brunton NP, Hossain MB, Rai DK, Collins SG, Jones PW, Maguire AR and O'Brien NM: Anti-inflammatory properties of potato glycoalkaloids in stimulated Jurkat and Raw 264.7 mouse macrophages. Life Sci 92: 775-782, 2013

21. Lv C, Kong H, Dong G, Liu L, Tong K, Sun H, Chen B, Zhang C and Zhou M: Antitumor Efficacy of $\alpha$-Solanine against pancreatic cancer in vitro and in vivo. PLoS One 9: e87868, 2014. 
22. Gao SY, Wang QJ and Ji YB: Effect of solanine on the membrane potential of mitochondria in HepG2 cells and [Ca2+]i in the cells. World J Gastroenterol 12: 3359-3367, 2006.

23. Ji YB, Gao SY, Ji CF and Zou X: Induction of apoptosis in HepG2 cells by solanine and Bcl-2 protein. J Ethnopharmacol 115: 194-202, 2008

24. Shen KH, Liao AC, Hung JH, Lee WJ, Hu KC, Lin PT, Liao RF and Chen PS: $\alpha$-Solanine inhibits invasion of human prostate cancer cell by suppressing epithelial-mesenchymal transition and MMPs expression. Molecules 19: 11896-11914, 2014.

25. Kang H, Jeong HD and Choi HY: The chloroform fraction of Solanum nigrum suppresses nitric oxide and tumor necrosis factor- $\alpha$ in LPS-stimulated mouse peritoneal macrophages through inhibition of p38, JNK and ERK1/2. Am J Chin Med 39: 1261-1273, 2011

26. Wang JY, Jia XH, Xing HY, Li YJ, Fan WW, Li N and Xie SY: Inhibition of Forkhead box protein M1 by thiostrepton increases chemosensitivity to doxorubicin in T-cell acute lymphoblastic leukemia. Mol Med Rep 12: 1457-1464, 2015.

27. Sengupta A, Banerjee D, Chandra S, Banerji SK, Ghosh R, Roy R and Banerjee S: Deregulation and cross talk among Sonic hedgehog, Wnt, Hox and Notch signaling in chronic myeloid leukemia progression. Leukemia 21: 949-955, 2007.

28. Abdallah HM, Al-Abd AM, El-Dine RS and El-Halawany AM: P-glycoprotein inhibitors of natural origin as potential tumor chemo-sensitizers: A review. J Adv Res 6: 45-62, 2015.

29. Friedman M: Chemistry and anticarcinogenic mechanisms of glycoalkaloids produced by eggplants, potatoes, and tomatoes. J Agric Food Chem 63: 3323-3337, 2015.

30. Friedman M, Lee KR, Kim HJ, Lee IS and Kozukue N: Anticarcinogenic effects of glycoalkaloids from potatoes against human cervical, liver, lymphoma, and stomach cancer cells. J Agric Food Chem 53: 6162-6169, 2005.
31. Wang XB, Wang SS, Zhang QF, Liu M, Li HL, Liu Y, Wang JN, Zheng F, Guo LY and Xiang JZ: Inhibition of tetramethylpyrazine on P-gp, MRP2, MRP3 and MRP5 in multidrug resistant human hepatocellular carcinoma cells. Oncol Rep 23: 211-215, 2010.

32. Yan F, Wang XM, Liu ZC, Pan C, Yuan SB and Ma QM: JNK1, JNK2, and JNK3 are involved in P-glycoprotein-mediated multidrug resistance of hepatocellular carcinoma cells. Hepatobiliary Pancreat Dis Int 9: 287-295, 2010.

33. Tang PM, Zhang DM, Xuan NH, Tsui SK, Waye MM, Kong SK, Fong WP and Fung KP: Photodynamic therapy inhibits p-glycoprotein mediated multidrug resistance via JNK activation in human hepatocellular carcinoma using the photosensitizer pheophorbide a. Mol Cancer 8: 56, 2009.

34. Comerford KM, Cummins EP and Taylor CT: c-Jun $\mathrm{NH} 2$-terminal kinase activation contributes to hypoxia-inducible factor 1alpha-dependent P-glycoprotein expression in hypoxia. Cancer Res 64: 9057-9061, 2004.

35. Ronaldson PT, Ashraf T and Bendayan R: Regulation of multidrug resistance protein 1 by tumor necrosis factor $\alpha$ in cultured glial cells: Involvement of nuclear factor-kappaB and c-Jun N-terminal kinase signaling pathways. Mol Pharmacol 77: 644-659, 2010

36. Findlay VJ, Townsend DM, Saavedra JE, Buzard GS, Citro ML, Keefer LK, Ji X and Tew KD: Tumor cell responses to a novel glutathione S-transferase-activated nitric oxide-releasing prodrug. Mol Pharmacol 65: 1070-1079, 2004.

37. Cripe LD, Gelfanov VM, Smith EA, Spigel DR, Phillips CA, Gabig TG, Jung SH, Fyffe J, Hartman AD, Kneebone P, et al: Role for c-jun N-terminal kinase in treatment-refractory acute myeloid leukemia (AML): Signaling to multidrug-efflux and hyperproliferation. Leukemia 16: 799-812, 2002. 